\title{
On the effectiveness of preventive services
}

\author{
Nadezhda Momot $^{1}$, Yuliya Kolina ${ }^{1, *}$, Aleksey Trebukhov ${ }^{2}$, Igor Kamliya ${ }^{1}$, and Andrey \\ Trebukhov ${ }^{3}$ \\ ${ }^{1}$ Primorskaya State Academy of Agriculture, 692510, Ussuriysk, Russian Federation \\ ${ }^{2}$ Altai State Agricultural University, 656049, Barnaul, Russian Federation \\ ${ }^{3}$ Altai State University, 656049, Barnaul, Russian Federation
}

\begin{abstract}
This article presents quantitative measures of the spread of epizootic foci of African swine fever (ASF) for 2020 in the Primorye Territory. Veterinarians of Primorye have undertaken a range of preventive services to eliminate the foci of the disease and prevent the spread of ASF. They include timely removal of sick animals from private subsidiary farmings. These measures resulted in the elimination of all epizootic foci in the territory of the region. The Veterinary service of the region continues preventive efforts towards prevention of new outbreaks.
\end{abstract}

\section{Introduction}

From ancient times, humanity has been involved in the raising and breeding of farm animals, including cattle, pigs, etc [1-3]. Meanwhile, people faced with various diseases affecting various organs, organ systems, and disordering metabolic processes [4,5]. This would eventually lead to a decline in animal productivity, even in one of the most profitable livestock industries - pig farming. The prospects of pig farming are ensured by the high fecundity, earliness and high slaughter yield of most pig breeds. Together with the traditional challenges of this industry, a new natural barrier to the development of pig farming has appeared in Primorye - the spread of the virus that causes African swine fever. This viral disease (Pestis africanasuum), which proceeds in the form of epizootics, is highly contagious, rapidly spreading, and characterized by a high mortality rate [6-9]. The ASF virus is a part of the iridovirus family and, owing to its intracytoplasmic localization, affects synthetic cellular processes by inhibiting cell proliferation [10,11]. Organs of hematopoiesis and immune defense are significantly affected - lymph nodes, spleen and tonsils. Necrotic and inflammatory processes in various organs are also presented. This virus is not dangerous for people, but in the meantime, laboratory tests indicate the presence of antibodies, which suggests the possibility of an asymptomatic form of ASF in people [12]. Mutational variabilities of the virus can cause unpredictable results, including the hazard to the human.

Virus carriers are all sick animals. The virus is spread everywhere in their tissues, mainly in the circulatory system.

\footnotetext{
*Corresponding author: momot18@mail.ru
} 


\section{Materials and methods}

For laboratory tests, samples of tissues, including blood, and parenchymal organs, such as lungs, lymph nodes, bone marrow, and spleen, were collected from dead animals, as well as from forcibly killed sick pigs.

Pathomorphological specimens from the animals were collected within 10 hours and examined by laboratory methods in order to diagnose African swine fever in conformance with the approved interstate standard: GOST 28573-90 [13]. According to the analysis of the results obtained while conducting laboratory tests of the delivered biological material and blood serum to establish the presence of the ASF virus, or antibodies to it, a diagnosis was made. African swine fever (ASF) was diagnosed in Primorye, both within farms and in wild boar populations, applying a set of laboratory research methods at the Primorye InterRegional Veterinary Laboratory of the Federal Service for Veterinary and Phytosanitary Surveillance.

\section{Results and discussion}

According to the conducted laboratory researches, the causative agent of a highly contagious disease in 2020 in the Primorye Territory was the reason for the manifestation of epizootic foci for this disease. The territory of the region is quite large and includes 12 urban districts and 22 municipal districts. ASF was revealed in the following localities:

- in Chuguevsky Municipal District;

- in the farms of Spassky district;

— in Yakovlevsky district;

- on the territory of Khasansky district;

— in Dalnerechensky district;

— in Lesozavodsky;

- on the territory of Anuchinsky district;

— in Arsenyevsky urban district;

— in Kirovsky district.

In the territory of the region, where 29 urban and 116 rural settlements are located, measures were held during 2020 to combat the dangerous disease. The illness is spread not only with infected wild boars living in the natural environment, but also through animal meat and household items. The fact that slaughterhouse products derived from diseased domestic pigs and wild boars are particularly dangerous was considered. Frequently, in farms, fresh slaughter products without any treatment, particularly heat treatment, were fed to healthy animals. This was another source of the disease spread. To eliminate carrying of infection, animal feed should be purchased from safe areas that are free of ASF disease. Additionally, the animal feed must be heat treated.

For a successful fight against African swine fever, the following must be complied with at the legislative level:

- on farms and entire rural areas where this disease is registered, shall be quarantine;

- all pigs shall be slaughtered in a bloodless manner in the ASF outbreak zone;

- animal carcasses are incinerated in situ;

- feed and equipment used for animal care should be burned;

- places where pigs are kept are subject to disinfection;

- it is necessary to implement deratization measures for rodents, insects, and stray animals in the ten-kilometer zone;

- enforce a strict ban on the export and sale of pig products for one month;

- pigs are not allowed to be raised in the quarantine zone during the year; 
- the quarantine is lifted within 40 days after the death of the last animal from African swine fever;

- young animals (piglets) should be purchased only if there are documents issued by veterinarians;

- after buying the animals, they must be kept in the quarantine zone for a while;

- it is required to inspect the animals and regularly vaccinate the livestock against popular diseases;

- places where pigs are kept and animal feed is stored should be systematically disinfected;

- the pig must not be in contact with other animals.

Veterinarians acquired experience in the fight against ASF back in 2019, when the virus of this disease was registered for the first time in the Primorye Territory.

Specialists used disinfection in unsatisfactory personal subsidiary farms, introduced quarantine restrictions, and established entrance points within the second threatened zone.

Thanks to the measures taken, epizootic outbreaks were eradicated by April 2020 [14,15].

Meanwhile, in the summer of 2020, new foci of African swine fever troubles appeared on the Primorye Territory. They spread in the most part (46 cases of the disease) in private subsidiary farms and in 22 cases-in the wild.

For elimination of epizootic challenges for this disease, the Federal Service for Veterinary and Phytosanitary Surveillance of the Primorye Territory and the Sakhalin Region, with the participation of leading specialists of the Federal State Budgetary Institution "Primorskaya MVL", has designed a list of preventive services, which is detailed in the ASF control plan. Since when confirming the diagnosis of ASF, sick animals are not subject to treatment, they are taken out and then killed.

Preventive services to fight against ASF include: burning the corpses of infected animals; killing the waste products of the dead animals; treatment with a hot solution of $3 \%$ sodium hydroxide or $2 \%$ formaldehyde solution of the whole area of farms, including places where animals kept; disposal of pigs in the ten-kilometer zone surrounding the disease site, while meat and slaughter products are processed for canned food.

On the basis of the proposed services to fight against ASF and the plan of preventive measures, including the timely removal of sick animals from private farms, all foci of African swine fever in the entire territory of the Primorye Territory, including 29 urban and 116 rural settlements, were fully revitalized at the end of December 2020. Totally, 1,781 pigs were taken in the region of private subsidiary farms during the foci of this infectious disease and in the first threatened zone, for which the livestock breeders got compensations from the regional budget in the amount of more than 16 million rubles.

\section{Conclusion}

- In the Primorye Territory, covering an area of $165900 \mathrm{~km} 2$, for the first time in 2019, a particularly dangerous contagious disease called African swine fever-was registered.

- African swine fever (ASF) was diagnosed in Primorye, both within farms and in wild boar populations. A complex of laboratory research methods was used at the Primorye Interregional Veterinary Laboratory of the Federal Service for Veterinary and Phytosanitary Surveillance (FSBI "Primorskaya MVL").

- In order to eliminate epizootic difficulties with this disease, the Federal Service for Veterinary and Phytosanitary Surveillance of the Primorye Territory and the Sakhalin Region, with the participation of leading specialists of the Federal State Budgetary Institution "Primorskaya MVL", has designed a list of preventive services, thoroughly reflected in the plan for the fight against ASF. 
- Totally, 1,781 pigs were taken in the region of private subsidiary farms during the foci of this infectious disease and in the first threatened zone, for which the livestock breeders got compensations from the regional budget in the amount of more than 16 million rubles. Animal owners do not give up hope for the prospect of restoring the pig industry of animal breeding.

- On the basis of the services offered by veterinarians to fight against ASF and the plan of preventive measures, including the timely elimination of sick animals from personal subsidiary farms, all foci of African swine fever throughout the Primorye Territory at the end of December 2020 are fully revitalized.

- Therefore, veterinary specialists of Primorye have undertaken the main services to eliminate epizootic foci and prevent the spread of ASF. These steps have resulted in the elimination of all epizootic foci in the Primorye Territory, including 29 urban and 116 rural settlements. Veterinary service of the region keeps up work aimed at preventing the occurrence of new outbreaks.

\section{References}

1. N.V. Momot, Morphological evidence on the presence of pig production in the territory of ancient Primorye, Issues of species and age morphology: proceedings of the AllRussian Research and Practice Conference with International Participation devoted to the 100th anniversary of Professor Kirill Antonovich Vasiliev, 86 (2019)

2. N.V. Momot, On the development of pig breeding in the territory of ancient Primorye, Actual issues and innovative technologies in veterinary medicine, animal husbandry and environmental protection: proceedings of the International Research and Practice Conference devoted to the 40th anniversary of the establishment of the Veterinary Faculty, 126 (2019)

3. A.V. Trebukhov, A.A. Elenshleger, S.P. Kovalev, Ketosis of dairy cows: a monograph, 173 (2016)

4. A.V. Trebukhov, Vest. Alt. Gos. Agrar. Univers., 8 (166), 95 (2018)

5. A.V. Trebukhov, A.A. Elenshleger, IOP Conference Series: Earth and Environmental Science. The proceedings of the conference AgroCON-2019, (2019)

6. I.V. Knysh, Spread of African swine fever virus in the territory of the Russian Federation. Scientific assistance in the development of the agroindustrial complex under import substitution, St. Petersburg State Agrarian University, 236 (2018)

7. K. Gruzdev, Myasn. promy., 3(118), 18 (2017)

8. V.M. Gulenkin, Tr. Fed. Tsent. Okhr. Zdor. Zhiv., 14, 31(2016)

9. A.F.O. Kadirov, Problem. vet. san. gig. i ek., 1(5), 124 (2011)

10. A.M. Smirnov. Veter. vrach., 3, 2 (2012)

11. N.V. Tarlavin, Nauch. zh., 4(5), 33 (2016)

12. V.V. Makarov, Vest. Rossel'k., 3, 68 (2013)

13. Pigs. Methods of laboratory diagnostics of african plague

14. N.V. Momot, Svinovodstv, 7, 58 (2020)

15. N.V. Momot, Vest. Alt. Gos. Agrar. Univers., 11 (193), 99 (2020) 